\title{
Bentuk-Bentuk Partisipasi Masyarakat Kawasan Wisata Pantai Pidakan di Kecamatan Tulakan, Kabupaten Pacitan
}

\author{
Ema Umilia ${ }^{1}$ \\ Lina Rizqi Nafisah ${ }^{2}$ \\ ${ }^{1}$ Urban and Regional Planning Department, Institut Teknologi Sepuluh Nopember, Indonesia \\ Email : umilia84@gmail.com
}

\begin{abstract}
ABSTRAK
Kawasan wisata Pantai Pidakan berpotensi untuk dikembangkan karena menawarkan keindahan alam yang berbeda dibandingkan dengan pantai yang lainnya di Pacitan dengan panorama pantai berbatu. Pengembangan wisata pantai Pidakan dikelola secara partisipatif oleh masyarakat Desa Jetak, Kabupaten Pacitan. Namun kawasan wisata pantai Pidakan belum optimal karena terkendala pada kurangnya pengembangan atraksi, fasilitas serta rendahnya dukungan pemerintah dan pihak lainnya. Sehingga penelitian ini bertujuan untuk mengidentifikasi bentuk-bentuk partisipasi masyarakat kawasan wisata Pantai Pidakan. Berdasarkan hasil analisis didapatkan bahwa, pertama, bentuk partisipasi yang tertinggi adalah partisipasi buah pikiran yang berpotensi untuk dikembangkan. Dengan dikembangkannya partisipasi buah pikiran masyarakat akan memiliki inovasi-inovasi terbaru untuk mengembangkan kawasan wisata Pantai Pidakan. Partisipasi terendah adalah bentuk partisipasi keterampilan sehingga perlunya peningkatan keterampilan dalam pengembangan wisata.
\end{abstract}

Kata Kunci : Pengembangan Wisata, Wisata Pantai, Partisipasi Masyarakat 


\section{PENDAHULUAN}

Pariwisata merupakan salah satu faktor penting dalam perkembangan perekonomian Indonesia. Hal ini karena pariwisata merupakan ujung tombak dari kemajuan perekonomian suatu negara. Tujuan pengembangan pariwisata akan berhasil dengan optimal bila ditunjang oleh potensi daerah yang berupa objek wisata baik wisata alam maupun wisata buatan manusia. Pembangunan dan pengembangan daerah menjadi daerah tujuan wisata tergantung dari daya tarik wisata itu sendiri yang dapat berupa keindahan alam, tempat bersejarah, tata cara hidup bermasyarakat maupun upacara keagamaan. [1]

Kabupaten Pacitan dikenal memiliki kawasan wisata pantai yang banyak dengan daya tarik wisata yang beraneka ragam dan tidak sama dengan pantai satu dengan pantai yang lainnya. Salah satu Kawasan Pantai yang menarik di kunjungi yakni wisata Pantai Pidakan yang terletak di Desa Jetak, Kecamatan Tulakan. [2]

Kawasan wisata Pantai Pidakan berpotensi untuk dikembangkan. Pantai Pidakan sendiri menawarkan keindahan alam yang berbeda dibandingkan dengan pantai-pantai yang ada di Kabupaten Pacitan yaitu dengan adanya hamparan batu putih berserta pasir putihnya, sebagai tempat memancing, adanya tebing dengan bukit diatasnya, serta penghijauan dengan tanaman kelapa sehingga menciptakan suasana nyaman bagi wisatawan yang berkunjung. Hingga saat ini, pengembangan wisata Pantai Pidakan dikelola oleh masyarakat Dusun Godeg Kulon, Desa jetak. Hal ini di dukung oleh tingkat partisipasi masyarakat yang tinggi yang dilakukan secara kelompok oleh masyarakat setempat dalam hal pengelolaan wisata pantai. Partisipasi merupakan sebuah proses dimana masyarakat sebagai stakeholder, terlibat dalam proses pembuatan keputusan yakni merumuskan program-program, menilai program itu dapat mencapai tujuan, merencanakan dan menilai besaran biaya.
Jenis partisipasi masyarakat terdiri dari partisipasi buah pikiran, partisipasi tenaga, partisipasi harta benda, partisipasi keterampilan, dan partisipasi sosial [3].

Kawasan wisata Pantai Pidakan menjadi denyut nadi ekonomi warga setempat, terutama warga Desa Jetak. Keuntungan ekonomis tersebut mereka dapatkan dari banyaknya pengunjung yang datang ke pantai ini, terutama setiap akhir pekan. Adanya warung - warung kecil yang berjejer di pinggir pantai selain itu warga desa mendapatkan tambahan penghasilan dari jasa ojek pada pintu masuk yang ditawarkan oleh warga setempat. Selain itu wisata Pantai Pidakan dilalui oleh Jalur Lintas Selatan (JLS) dan akses jalan menuju kawasan wisata sudah menggunakan jalan aspal sehingga memudahkan wisatawan yang berkunjung. Utilitas yang ada di kawasan wisata pantai Pidakan juga sudah tersedia dengan baik seperti jaringan telepon, jaringan air bersih, jaringan listrik. Fasilitas yang dapat digunakan pengunjung pun sudah cukup baik seperti adanya MCK, dan musholla. [4]

Namun, masih terdapat masalah dalam pengembangan kawasan Pantai Pidakan, berupa lahan daerah sekitar pantai yang masih milik perseorangan dari warga Desa Jetak, sehingga pemerintah maupun pengembang kurang terlibat dalam mendukung pengembangan kawasan ini dan tidak dapat secara optimal mengembangkan kawasan wisata pantai. Masalah tersebut lah yang membuat kawasan wisata Pantai Pidakan tidak tercantum dalam arahan RTRW kabupaten Pacitan dikarenakan lahan yang ada milik warga Desa Jetak. [5]

Permasalahan yang lain yakni kurang beragamnya atraksi wisata sehingga menyebabkan kurangnya jumlah kunjungan wisatawan. Semakin bagus atraksi wisata, semakin banyak pula permintaan untuk mengunjungi kawasan wisata tersebut dan semakin berkembang pula atraksi wisata tersebut. Berdasarkan permasalahan tersebut diatas maka diperlukan penelitian untuk 
mengidentifikasi dan mengembangkan bentuk partisipasi masyarakat pantai Pidakan dalam mengembangkan wisatanya. Partisipasi masyarakat adalah keikutsertaan seluruh anggota masyarakat dalam memecahkan permasalahan yang ada di wisata Pantai Pidakan. Dalam hal ini, masyarakat sendirilah yang aktif memikirkan, merencanakan, melaksanakan dan mengevaluasi program-program demi pengembangan wisata Pantai Pidakan. Melalui penelitian ini diharapkan dapat menjadi masukan bagi pelaku pembangunan untuk mengoptimalkan pengembangan kawasan wisata Pantai Pidakan. [6]

\section{METODE PENELITIAN} Jenis dan Pendekatan Penelitian

Pendekatan yang digunakan dalam penelitian ini adalah pendekatan rasionalistik [7]. Jenis penelitian dalam penelitian ini adalah deskriptif kualitatif.

\section{Variabel Penelitian}

1. Variabel bentuk partisipasi yang digunakan dalam penelitian ini, antara lain :

- Partisipasi buah pikiran meliputi Ide/gagasan, pendapat, saran

- Partisipasi tenaga meliputi perbaikan/ pembangunan, aktivitas sosial dengan sukarela

- Partisipasi keterampilan meliputi pelatihan, bantuan Skill

- Partisipasi harta benda meliputi uang, barang, penyediaan Prasarana/ Sarana

2. Variabel pengembangan yang digunakan dalam penelitian ini, antara lain:

- Jenis wisata alam yang terdapat di Pantai Pidakan

- Jenis kebudayaan yang terdapat di Pantai Pidakan

- Keunikan dalam objek wisata

- Jenis atraksi kegiatan yang terdapat pada kawasan

- Ketersediaan toko souvenir
- Ketersediaan warung/ depot

- Ketersediaan tempat parkir

- Ketersediaan fasilitas peribadatan

- Ketersediaan fasilitas keamanan umum

- Ketersediaan pusat informasi

- Ketersediaan MCK

- Ketersediaan fasilitas penginapan

- Ketersediaan pelayanan jaringan air bersih

- Ketersediaan pelayanan sistem drainase

- Ketersediaan pelayanan jaringan listrik

- Ketersediaan jaringan telekomunikasi

- Ketersediaan moda angkutan umum menuju objek wisata

- Kondisi jalan menuju objek wisata

- Ketersediaan informasi melalui papan penunjuk

- Ketersediaan informasi melalui sosial media

- Ketersediaan informasi di pusat pariwisata

\section{Populasi dan Sampel}

Responden penelitian ini ditentukan dengan metode purposive sampling terhadap populasi yaitu masyarakat yang tinggal di Dusun Godeg Kulon, Desa Jetak Kecamatan Tulakan, Kabupaten Pacitan. Jumlah responden yang dibutuhkan dalam mengidentifikasi bentuk-bentuk partisipasi masyarakat sebanyak 30 orang dengan penentuan kriteria:

1. Termasuk kedalam pengelola kawasan wisata Pantai Pidakan

2. Mengikuti perkumpulan karang taruna di kawasan wisata Pantai Pidakan

3. Memahami kawasan wisata Pantai Pidakan sebagai kawasan wisata pantai

4. Terlibat langsung dalam pengelolaan Obyek Wisata Pantai Pidakan

\section{Teknik Pengumpulan Data}

Teknik yang dilakukan dalam penelitian ini sebagai berikut:

1. Wawancara

Wawancara dilakukan untuk mengetahui bentuk-bentuk partisipasi 
masyarakat yang sudah dilakukan maupun yang belum dilakukan di kawasan wisata Pantai Pidakan.

2. Observasi

Observasi yang dilakukan untuk mengetahui kondisi fisik yang meliputi atraksi wisata, keindahan alam/ pantai, prasarana dan sarana, transportasi/ aksesibilitas, fasilitas pendukung pada kawasan wisata Pantai Pidakan.

\section{Analisa Identifikasi Bentuk-Bentuk Partisipasi Masyarakat di Kawasan Wisata Pantai Pidakan}

Analisis ini bertujuan untuk mencapai sasaran dalam tujuan penelitian, yaitu mengidentifikasi bentuk-bentuk partisipasi masyarakat di kawasan wisata Pantai Pidakan. Analisis ini menggunakan teknik analisis deskriptif. Dalam tahapan analisa deskriptif , ada beberapa tahap yang akan dilakukan, antara lain:

1. Wawancara responden masyarakat menggunakan kuisioner

2. Pengelompokkan menurut bentukbentuk partisipasi masyarakat

3. Tabulasi silang antara bentuk-bentuk partisipasi masyarakat dengan variabel pengembangan

Tabel 1. Contoh Tabulasi Silang Bentukbentuk Partisipasi Masyarakat Berdasarkan Variabel Pengembangan Kawasan Wisata

\begin{tabular}{|c|c|c|c|c|c|}
\hline \multicolumn{6}{|c|}{ Pantai } \\
\hline & \multicolumn{5}{|c|}{ Bentuk Partisipasi } \\
\hline $\begin{array}{l}\text { Pengemba } \\
\text { ngan }\end{array}$ & Bentuk A & Bentuk B & Bentuk C & Bentuk I & \\
\hline $\begin{array}{l}\text { Variabel } \\
\text { A }\end{array}$ & $\begin{array}{l}\text { Bentuk } \\
\text { Partisipasi } \\
\text { A terhadap } \\
\text { variabel A }\end{array}$ & $\begin{array}{l}\text { Bentuk } \\
\text { Partisipasi B } \\
\text { terhadap } \\
\text { variabel A }\end{array}$ & $\begin{array}{l}\text { Bentuk } \\
\text { Partisipasi C } \\
\text { terhadap } \\
\text { variabel A }\end{array}$ & $\begin{array}{l}\text { Bentuk } \\
\text { Partisipasi } \\
\text { terhadap } \\
\text { variabel A }\end{array}$ & $\mathrm{D}$ \\
\hline $\begin{array}{l}\text { Variabel } \\
\text { B }\end{array}$ & $\begin{array}{l}\text { Bentuk } \\
\text { Partisipasi } \\
\text { A terhadap } \\
\text { variabel B }\end{array}$ & $\begin{array}{l}\text { Bentuk } \\
\text { Partisipasi B } \\
\text { terhadap } \\
\text { variabel B }\end{array}$ & $\begin{array}{l}\text { Bentuk } \\
\text { Partisipasi C } \\
\text { terhadap } \\
\text { variabel B }\end{array}$ & $\begin{array}{l}\text { Bentuk } \\
\text { Partisipasi } \\
\text { terhadap } \\
\text { variabel B }\end{array}$ & $\mathrm{D}$ \\
\hline $\begin{array}{l}\text { Variabel } \\
\text { C }\end{array}$ & $\begin{array}{l}\text { Bentuk } \\
\text { Partisipasi } \\
\text { A terhadap } \\
\text { variabel C }\end{array}$ & $\begin{array}{l}\text { Bentuk } \\
\text { Partisipasi B } \\
\text { terhadap } \\
\text { variabel C }\end{array}$ & $\begin{array}{l}\text { Bentuk } \\
\text { Partisipasi C } \\
\text { terhadap } \\
\text { variabel C }\end{array}$ & $\begin{array}{l}\text { Bentuk } \\
\text { Partisipasi } \\
\text { terhadap } \\
\text { variabel C }\end{array}$ & D \\
\hline
\end{tabular}

Sumber: Hasil Analisis, 2016

\section{HASIL DAN PEMBAHASAN}

Hasil dan pembahasan dalam penelitian ini dijelaskan menurut sasaran penelitian, yaitu sebagai berikut :

\section{Mengidentifikasi \\ Bentuk-Bentuk Partisipasi Masyarakat di Kawasan Wisata Pantai Pidakan}

Bentuk bentuk partisipasi masyarakat yang telah/ belum dilakukan masyarakat setempat dalam mengembangkan kawasan wisata Pantai Pidakan kemudian di analisis tabulasi silang pada masing-masing variabel pengembangan, sehingga didapatkan:

1. Partisipasi Buah Pikiran

Masyarakat memberikan usulan berupa konsep tempat yang nyaman untuk menikmati keindahan pantai dan usulan penyediaan/ penambahan/ memperlebar sarana-sarana yang terdapat di Pantai Pidakan.

2. Partisipasi Tenaga

Ikut berpartisipasi dalam budaya karawitan dan masyarakat secara aktif bergotong royong dalam membangun sarana dan prasarana dikawasan wisata pantai.

3. Partisipasi Keterampilan

Masyarakat secara aktif melakukan keterampilan dalam budaya karawitan yang diadakan setiap 1 tahun sekali.

4. Partisipasi Harta Benda Masyarakat yang memiliki ekonomi lebih dapat membangun warung, tempat penginapan guna menambah penghasilan. Beberapa masyarakat menghibahkan tanahnya untuk keperluan pelebaran jalan.

Dalam analisis ini dilakukan identifikasi stakeholders sebagai responden penelitian yakni masyarakat Dusun Godeg Kulon dengan menggunakan kriteria responden. Bentuk-Bentuk partisipasi masyarakat yang didapatkan dari hasil sintesa pustaka terdiri dari empat macam bentuk yakni partisipasi buah pikiran, tenaga, keterampilan dan harta benda.

Berdasarkan hasil analisa yang telah didapat dari hasil tabulasi silang antara variabel pengembangan dan bentuk-bentuk 
partisipasi masyarakat didapatkan bahwa:

1. Partisipasi buah pikiran merupakan bentuk partisipasi tertinggi yang terdapat di kawasan wisata Pantai Pidakan dari 21 variabel yang ada, 2 diantaranya tidak terdapat partisipasi ide/ gagasan yang diberikan masyarakat sekitar sehingga berpotensi untuk dikembangkan. Dengan dikembangkannya partisipasi buah pikiran masyarakat akan memiliki inovasi-inovasi terbaru untuk mengembangkan kawasan wisata Pantai Pidakan.

2. Partisipasi tenaga yang terdapat di kawasan wisata Pantai Pidakan dari 21 variabel yang ada, 6 diantaranya tidak terdapat partisipasi tenaga yang dilakukan oleh masyarakat sekitar.

3. Partisipasi harta benda yang terdapat di kawasan wisata Pantai Pidakan dari 21 variabel yang ada, 14 diantaranya tidak terdapat partisipasi uang dan merupakan partisipasi terendah ketiga dari 4 jenis partisipasi.

4. Partisipasi keterampilan merupakan partisipasi terendah di kawasan wisata Pantai Pidakan. Partisipasi keterampilan yang terdapat di kawasan wisata Pantai Pidakan dari 21 variabel yang ada hanya 1 variabel yang memiliki partisipasi berupa keterampilan yakni jenis kebudayaan berupa karawitan. Sehingga perlunya pelatihan keterampilan seperti keterampilan mengolah souvenir ataupun pelatihan atraksi yang disuguhkan untuk menarik minat wisatawan yang berkunjung.

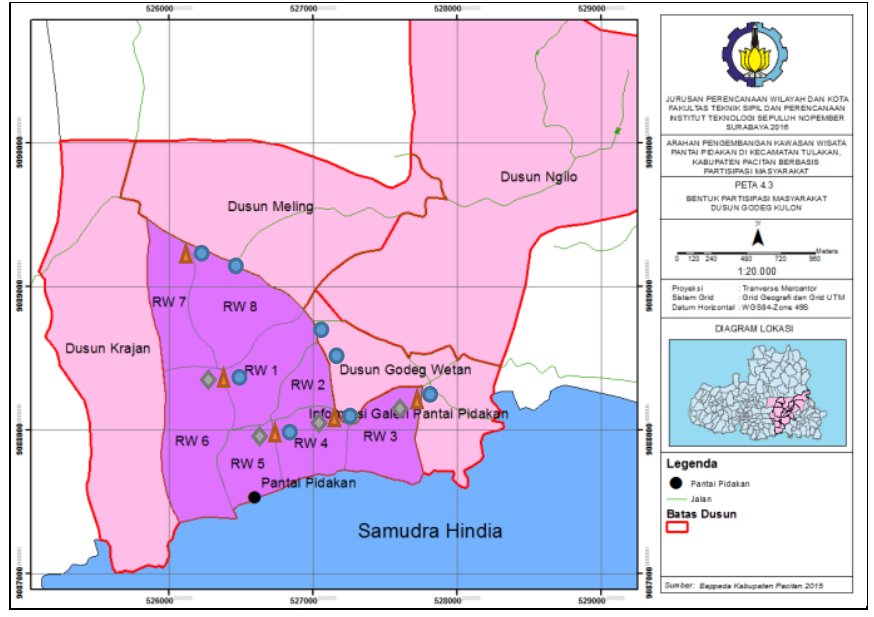

Gambar 2. Bentuk Partisipasi Masyarakat Dusun Godeg Kulon

Berikut merupakan penjelasan dari simbol peta bentuk partisipasi masyarakat yang telah dilakukan oleh masyarakat wisata Pantai Pidakan:

- Segitiga merupakan jenis partisipasi tenaga

- Lingkaran merupakan jenis partisipasi harta benda dan keterampilan

- Wajik merupakan bentuk partisipasi buah pikiran

\section{KESIMPULAN}

Berdasarkan hasil analisis yang telah dilakukan mengenai bentuk-bentuk partisipasi masyarakat kawasan wisata Pantai Pidakan yang telah diuraikan sebelumnya, maka dapat ditarik kesimpulan : Didapatkan bentuk-bentuk partisipasi masyarakat di kawasan wisata Pantai Pidakan. Terdapat empat (4) bentuk partisipasi masyarakat di kawasan wisata Pantai Pidakan yakni partisipasi buah pikiran yang paling tinggi bentuk partisipasinya yaitu berupa jenis wisata alam, ketersediaan toko souvenir, fasilitas keamanan umum, lalu partisipasi tenaga yaitu ketersediaan pelayanan sistem drainase selanjutnya partisipasi harta benda yaitu ketersediaan warung/ depot, dan partisipasi keterampilan merupakan bentuk partisipasi terendah dibandingkan jenis partisipasi yang lain, sehingga diperlukan 
upaya peningkatan keterampilan atraksi kegiatan dan souvenir khas Pantai Pidakan.

\section{DAFTAR PUSTAKA}

[1] Yoeti (1985) A.J., Muljadi, Kepariwisataan dan Perjalanan, Jakarta: PT Raja Grafindo Persada, 2012.

[2] Marpaung, S. M. (2002). Pengetahuan Kepariwisataan. Jakarta: Badan Pengembangan Kebudayaan dan Pariwisata.

[3] Marpaung, Happy dan Bahar, Herman, Pengantar Pariwisata, Bandung: CV. Alfabeta, 2002.

[4] Ismayanti. (2010). Pengantar Pariwisata. Jakarta: PT Gramedia.

[5] DRS. H. Oka A. Yoeti, M. (2005). Perencanaan Strategis Pemasaran Daerah Tujuan Wisata. Jakarta: PT Pradnya Paramita.

[6] Hermantoro, H. (2011). CreativeBased Tourism Dari Wisata Rekreatif Menuju Wisata Kreatif. Depok: Aditri.

[7] O, Y. (1995). Tours and Travel Management, edisi revisi. Jakarta: PT Pradnya Paramita.

[8] Prasiasa, D. P. (2013). Destinasi Pariwisata Berbasis Masyarakat. Jakarta: Salemba Humanika.

[9] Spillane, J. J. (1991). Ekonomi Pariwisata: Sejarah dan Prospeknya. Yogyakarta: Deresan, Yogyakarta.

[10] Suwena, I Ketut dan Widyatmaja, I Gst Ngr, Pengetahuan Dasar Ilmu Pariwisata, Bali: Udayana University Pres, 2010.

[11] Sugiono. 2009. Metode Penelitian Kuantitatif, Kualitatif dan R \& D. Bandung : Alfabeta

[12] Turindra, A. (2009, Juni). Pengertian Partisipasi. Retrieved from Turindra Corporation Indonesia (TCI): http://turindraatp.blogspot.co.id/2009/0 6/pengertian-partisipasi.html

[13] Nuring Septyasa Laksana. (2013). Kebijakan dan Manajemen Publik. Bentuk-bentuk Partisipasi Masyarakat Desa dalam Program Desa Siaga di Desa Bandung Kecamatan Playen
Kabupaten Gunung Kidul Provinsi Daerah Istimewa Yogyakarta, 5-6. 
